\title{
Ekologi Penciptaan dalam Kejadian 1-3 sebagai Landasan Evaluasi Kritis terhadap Perilaku Ekologis Para Teolog Reformed Indonesia Masa Kini
}

\author{
Agustina Pasang \\ Unit Penjamin Mutu Internal Sekolah Tinggi Teologi Excelsius \\ agustinapasang@sttexcelsius.ac.id
}

\begin{abstract}
Ecological (environmental) problems are the responsibility of all human beings, both personal and group, including the responsibilities of all religions or beliefs. Even so, it must be admitted that the topic of ecology and all its problems are lacking or not or even not getting attention as they should. Ecological topics tend to be distinguished, not or lacked attention by both churches and Christian theologians and reform theologians in particular with indications of a lack of Christian literature that addresses topics concerning ecology. There is no or lack of studies (seminars, lectures) on ecology both in the church environment, Christian institutions and theological colleges, besides that there is a misunderstanding which feels that ecology does not touch or come into contact with theology. This understanding appears in behavior that is not or less responsible for the environment (not friendly to the environment), for example by littering, spitting carelessly and so on.
\end{abstract}

Keywords: Ecology; Evaluation; Teolog; Reformed; Indonesia

\begin{abstract}
Abstrak
Permasalahan ekologis (lingkungan) merupakan tanggung jawab semua manusia baik bersifat pribadi maupun kelompok, termasuk di dalamnya tanggung jawab semua agama atau aliran kepercayaan. Meskipun demikian harus diakui bahwa topik ekologi dan semua permasalahannya kurang atau belum atau bahkan tidak mendapat perhatian sebagaimana seharusnya. Topik ekologi cenderung dianaktirikan, tidak atau kurang mendapat perhatian baik oleh gereja-gereja maupun para teolog Kristen dan teolog reform pada khususnya dengan indikasi kurangnya literatur-literatur Kristen yang membahas topik mengenai ekologi. Tidak ada atau kurangnya kajian-kajian (seminar, ceramah) mengenai ekologi baik di lingkungan gereja, lembaga-lembaga Kristen dan Sekolah Tinggi Teologi, selain itu adanya salah pengertian (misunderstanding) yang merasa bahwa ekologi tidak bersinggungan atau bersentuhan dengan teologi. Pemahaman ini nampak dalam perilaku yang tidak atau kurang bertanggung jawab terhadap lingkungan (tidak ramah terhadap lingkungan), misalnya dengan membuang sampah sembarangan, meludah sembarangan dan lain sebagainya.
\end{abstract}

Kata Kunci: Ekologi; Evaluation; Teolog; Reformed; Indonesia 


\section{PENDAHULUAN}

Persoalan ekologi bukan hanya persoalan lingkungan sosial, ekonomi atau persoalan manusia saja, tetapi juga persoalan kemiskinan dan tentunya hal ini berakar pada krisis moral manusia itu sendiri, dengan kata lain manusia menjadi faktor utama terhadap kerusakan lingkungan dan manusia menderita akibat kejahatannya sendiri. Padahal dari sejak semula Allah telah mempercayakan kepemimpinan terhadap alam itu kepada manusia untuk mengelola dan memelihara ciptaan-Nya tersebut (Kej. 1-2). Namun pada kenyataannya tidak semua tugas itu berjalan dengan baik, hal ini terbukti dengan banyaknya pengrusakan alam (eksploitasi alam) yang dilakukan oleh manusia, misalnya pencemaran tanah dengan membuang zat-zat detergen, asam belerang dan zat kimia sebagai sisa pembuangan pabrik kimia/industri, pupuk tanaman yang merupakan unsur pulutan membuat mutu tanah berkurang bahkan dapat membahayakan. Zat kimia lainnya yaitu DDT (Dichloro-Diphenyl-Trichloroethane), aldrin, endrin, fosfor organik yang dapat membunuh mikro organisme atau jazat renik yang sangat penting bagi tanah untuk proses sintesa dan insektisida. ${ }^{2}$

\footnotetext{
${ }^{1}$ Stevri Indra Lumintang, Theology The Queen of Science \& The Master of Philosophy (Jakarta: Geneva Insani Indonesia, 2015)., 237.

2 I. Supardi, Lingkungan Hidup dan Kelestariannya (Bandung: Alumni, 1983), 41-42.
}

Pengolahan tanah yang terlalu intensif dengan menggunakan bahan kimia serta pembukaan daerah pertambangan mengganggu kesuburan tanah, selain itu pembuangan sampah-sampah (plastik) dapat mengganggu keadaan kesuburan tanah. ${ }^{3}$ Penyebab lain adalah erosi, penggaraman, urbanisasi dan desertifikasi, penggunaan bahan kimia dan praktek monokultur dapat menghilangkan semua mikro organisme, sehingga dapat disimpulkan bahwa masalah pertanahan menghadapi tiga hal, yaitu: erosi, penggunaan pestisida dan lemahnya peraturan serta sistem penggunaan lahan. ${ }^{4}$

Pengerusakan terhadap alam yang dilakukan manusia juga nampak pada kerusakan lingkungan hidup pada air, misalnya dengan membuang sampah atau kotoran ke sungai serta air kotor dari industri pabrik yang mengandung gas-gas tertentu yang membahayakan seperti: gas methane, haidrogen, sulvida. Salah satu contohnya adalah pencemaran air raksa dan bahan kimia lainnya di teluk Jakarta, dimana dari beberapa penelitian membuktikan bahwa pencemaran merkuri cukup mengkhawatirkan karena oceanologi nasional membuktikan bahwa pada tahun 1986 ikan dan udang di perairan Jakarta

\footnotetext{
3 Ichsan, Kesehatan Lingkungan (Jakarta: Depdikbud, 1979), 16.

${ }^{4}$ Robert P. Borrong, Etika Bumi Baru (Jakarta: BPK Gunung Mulia, 2009), 58-62.
} 
mengandung merkuri melebihi ambang batas untuk dikonsumsi. ${ }^{5}$ Hal ini menunjukkan bahwa faktor yang sangat mempengaruhi timbulnya pencemaran lingkungan adalah faktor kepadatan penduduk dan akibat sampingan dari kemajuan teknologi dan industri, dimana faktor-faktor ini sangat mempengaruhi kehidupan sosial dan ekonomi penduduk. ${ }^{6}$ Jumlah penduduk yang terus bertambah memicu berdirinya industriindustri besar serta kemajuan teknologi lainnya sehingga membutuhkan jumlah tenaga pekerja yang cukup besar. Namun pembangunan industri yang terus meningkat ini jika tanpa dibarengi dengan perhatian terhadap alam akan mengakibatkan adanya pencemaran lingkungan seperti pencemaran udara, air dan bahkan tanah, sebagai akibat buangan dari industri-industri besar dan pertambangan. Masalah kepadatan penduduk merupakan titik pangkal permulaaan terjadinya masalah lingkungan. ${ }^{7}$ Dengan demikian jelas bahwa pertambahan jumlah penduduk pun dapat memberi dampak negatif bagi lingkungan.

Pengerusakan atau eksploitasi alam semakin lengkap dengan tragedi pembalakan hutan yang terjadi. Kerusakan hutan tropis semakin berkembang dan sangat

\footnotetext{
${ }^{5}$ Ibid., 40-41.

${ }^{6}$ Depdikbud, Keselamatan Lingkungan, untuk SGO (Jakarta: Mutiara, 1988), 14.

${ }^{7}$ Ibid., 20-21.
}

mengkhawatirkan sebab hutan tropis dianggap sebagai paru-paru bumi yang mampu mensirkulasi dan mentransformasi karbon dioksida menjadi oksigen, bila hutan tropis hancur maka seluruh dunia akan terkena dampaknya. Menurut Word Bank setiap tahun ada 10 sampai 20 juta hektar hutan tropis hancur, padahal hutan tropis merupakan ekosistem yang sangat penting bagi bumi dimana sebagian besar makhluk hidup di bumi berada di hutan tropis. ${ }^{8}$ Jika hal ini terus dibiarkan maka diperkirakan pada abad-21, hutan tropis tidak ada lagi.

Berdasarkan data World Bank, diketahui bahwa di dunia hanya Brazil dan Indonesia yang masih mempunyai hutan tropis cukup luas, namun ini tidak menjamin karena di Indonesia saja setiap tahun sekitar 600 ribu hektar sampai 2,5 juta hektar hutan tropis musnah. 9 Indonesia mengakui kerusakan hutan yang terjadi, namun juga mengklaim bahwa kerusakan itu bisa diantisipasi dengan aturan-aturan dalam penebangan, misalnya dengan memakai sistem tebang pilih (selective cutting) dan reboisasi. Pada kenyataannya aturan-aturan ini tidak berjalan dengan baik sehingga penebangan kayu hutan tetap berlangsung tanpa kendali, baik yang resmi maupun liar. ${ }^{10}$

\footnotetext{
${ }^{8}$ Hadi S. Ali Kodra, Global Warming, Banjir dan Tragedi Pembalakan Hutan (Bandung: Nuansa, 2008), 24.

${ }^{9}$ Ibid.

${ }^{10}$ Ibid., 25.
} 
Berdasarkan fakta yang ada, maka dapat dimengerti bahwa salah satu penyebab timbulnya masalah-masalah ekologi adalah ketidakpuasan manusia dan kecenderungan manusia yang materialistis sehingga memandang alam hanya bernilai ekonomi.

Krisis ekonomi yang terjadi di Indonesia memberikan dampak yang sangat buruk terhadap hutan yang kemudian dihubungkan dengan utang negara karena adanya bantuan dana dari CGI (Consultative Group of Indonesia) dengan harapan bahwa Indonesia bersikap serius menyikapi masalah kerusakan hutan, penebangan liar, penyelundupan kayu, pencurian log dan kebakaran hutan yang semakin menjadi-jadi. Saat ini CGI masih menunda komitmen bantuannya senilai 400 juta dollar AS untuk Indonesia karena persoalan hutan di atas. ${ }^{11}$ Lebih jauh tentang hal ini, Dr. Mubariq Ahmad, mantan direktur Lembaga Ekolabel Indonesia (LEI) sekaligus pakar ekonomi lingkungan, menyatakan:

\begin{abstract}
Kehancuran hutan di Indonesia sangat kompleks. Ia memberi contoh kasus ekspor log yang ramai dibicarakan, menurut Ahmad ada empat kriteria mengenai kasus itu. Pertama, ekspornya legal, lognya legal tapi kental KKN. Kedua, ekspornya legal, lognya legal, tapi sumber lognya ilegal (kawasan hutan konservasi misalnya). Ketiga, ekspornya legal, lognya ilegal, tapi surat-suratnya palsu. Keempat, ekspornya ilegal, lognya ilegal. "lebih dari $70 \%$ perdagangan kayu, baik untuk
\end{abstract}

\footnotetext{
${ }^{11}$ Kodra, Global Warming, Banjir dan Tragedi Pembalakan Hutan, 27-28.
}

dalam negeri maupun ekspor, adalah ilegal." 12

Kerusakan hutan semakin meningkat dengan maraknya penebangan liar, dipicu oleh pemerintah yang memberikan ijin untuk ekspor kayu gelondongan sejak tahun 1985. Sekalipun demikian lembaga-lembaga pemerintahan yang berhubungan dengan kehutanan tidak berdaya menghadapi kerusakan hutan, sebaliknya saling menutupi kesalahannya. ${ }^{13}$ Data-data ini menunjukkan dengan jelas bahwa kerusakan hutan yang terjadi adalah akibat ulah manusia sendiri yang hanya ingin memakai, memanfaatkan alam tetapi tidak menjalankan tugasnya untuk memelihara alam.

Pemerintahan manusia atas alam dilakukan hanya dengan menjalankan kuasa tanpa disertai kemuliaan dan hormat telah menjadi pemicu rusaknya hubungan manusia dengan alam. Manusia memperlakukan alam didorong oleh faktor-faktor pragmatisme (daya guna), rakus, masa bodoh dan tidak bertanggung jawab, akibatnya nilai ekologis yang mencakup nilai estetis, biologis dan nilai-nilai lainnya tidak mendapat perhatian yang sepatutnya. Penyalahgunaan kepemimpinan manusia atas ciptaan Allah menyebabkan manusia berdosa mempraktekkan hidup yang penuh ketakutan sekaligus kerakusan dan alam pun menjadi

\footnotetext{
${ }^{12}$ Ibid, 28.

${ }^{13}$ Ibid.
} 
sasarannya. ${ }^{14}$ Hal ini bertentangan dengan maksud Allah yang menghendaki agar orang Kristen bertanggung jawab terhadap lingkungannya termasuk terhadap krisis ekologi yang terjadi saat ini. tentang hal ini, John Stott menuliskan:

Bumi ini milik Allah sekaligus milik
manusia, milik Allah sebab Ia yang
menciptakannya, milik manusia sebab
Ia telah memberikannya kepada kita
tetapi dalam pengertian bukan
memberikannya sedemikian tuntas
sehingga Ia sama sekali tak punya hak
dan tak punya kontrol lagi atasnya,
melainkan memberikannya kepada kita
supaya kita menguasainya atas nama
Dia. ${ }^{15}$

Itu berarti penguasaan manusia atas bumi adalah berdasarkan hak pakai dan bukan berdasarkan hak milik, itu berarti harus ada pemulihan hubungan antara manusia dengan alam yang dimulai dari manusia, manusia harus kembali ke fitrahnya semula sebagai wakil Allah atas alam artinya manusia harus mencerminkan kemuliaan dalam menjalankan kuasa atas alam sekaligus menjadi representatif kemuliaan Allah atas alam.

Berdasarkan Kejadian 1 dan 2, paling tidak ada tiga penegasan yakni: pertama, Allah memberikan manusia kekuasaan atas bumi dimana kekuasaan yang unik atas bumi adalah hubungan yang unik dengan Allah. Kedua, Kekuasaan manusia atas bumi adalah

\footnotetext{
${ }^{14}$ Borrong, Etika Bumi Baru, 160.

15 John Stott, Isu-isu Global Menantang Kepemimpinan Kristen (Jakarta: YKBK/OMF, 1994), 150.
}

suatu kekuasaan kooperatif, artinya bahwa dalam menjalankan kekuasaan pemberian Allah, manusia bukannya menciptakan melainkan bekerja sama dengan prosesproses alami dan yang ketiga bahwa pendominasian manusia adalah pemberian karena itu suatu pendominasian yang bertanggung jawab dimana manusia menguasai bumi bukan berdasarkan hak melainkan berdasarkan perkenanan Allah. ${ }^{16}$ Dengan demikian jelas bahwa manusia bertanggung jawab kepada Allah dalam cara mengelola bumi ini. Lebih jauh mengenai hal ini, John Stott menuliskan:

kita tidak berhak memperlakukan
lingkungan alami semau kita; kita tidak
berhak berbuat semau kita. 'menguasai'
bukanlah sinonim dari 'merusak'.
Karena bumi ini adalah yang
dipercayakan kepada kita, maka kita
harus mengelola r serta
memproduktifkannya rara
bertanggung jawab demi kebaikan
generasi kita dan generasi-generasi
berikutnya. ${ }^{17}$

Hal itu semakin menjelaskan bahwa kepercayaan yang Allah berikan kepada manusia atas alam bukan sekedar untuk menggunakan alam semaunya tetapi dibarengi dengan tugas untuk memelihara, mengelola alam secara bertanggung jawab oleh karena apa yang dihasilkan bumi adalah untuk dinikmati semua orang.

\footnotetext{
16 Ibid, 150-154.

${ }^{17}$ Ibid, 156.
} 
Alam adalah ciptaan dan karya Allah, maka Allah adalah pemilik dan yang berdaulat atas seluruh ciptaan-Nya termasuk manusia. Alam mempunyai nilai intrinsik sebab alam diciptakan dengan baik oleh Allah. ${ }^{18}$ Artinya manusia sebagai wakil Allah memiliki tanggung jawab terhadap alam atau lingkungan karena itu merupakan mandat atau perintah dari Tuhan. Banyak orang Kristen berasumsi bahwa manusia adalah pusat dari tujuan dan maksud penciptaan jagad raya oleh Allah, pandangan ini dikenal sebagai prinsip 'anthropocentric,' yang diikuti oleh pemikiran bahwa dunia diciptakan hanya untuk dan bagi kepentingan manusia yang membuat manusia bangga atau memiliki rasa percaya diri yang tinggi dan menilai rendah ciptaan lain, kemudian pemahaman dan sikap ini tercermin dalam kegiatan eksploitasi terhadap ciptaan lain tanpa mempertimbangkan bahwa Allah menciptakan setiap ciptaan dengan tugas dan fungsinya masing-masing, tidak melulu untuk kepentingan manusia. ${ }^{19}$ Pandangan ini sekaligus menunjukkan bahwa manusia belum sepenuhnya menjalankan tugas tanggung jawabnya untuk memelihara, merawat, melestarikan serta mengembangkan alam, selain itu manusia cenderung memandang alam atau lingkungan

\footnotetext{
${ }^{18}$ Borrong, Etika Bumi Baru, 215.
}

hanya sebagai alat atau sarana untuk mencukupkan segala kebutuhan hidupnya.

Melaksanakan tanggung jawab untuk memelihara, merawat dan mengembangkan alam (lingkungan) merupakan satu bukti keimanan dan ketaatan kepada Tuhan. Dalam hal ini pemulihan hubungan manusia dengan alam selain disosialisasikan melalui gerejagereja maupun lembaga-lembaga Kristen yang merupakan wadah komunikasi orang Kristen, maka para teolog Kristen khususnya teolog reformed hendaknya memainkan peranan penting dalam memberikan, menanggapi, menjawab informasi mengenai tanggung jawab pemeliharaan lingkungan, isu-isu di seputar lingkungan dan krisis lingkungan baik dalam bentuk literatur, kajian (seminar, ceramah) untuk menjelaskan bahwa hubungan manusia dengan alam atau lingkungan yang selama ini telah rusak harus dipulihkan karena ekologi dan pemeliharaannya merupakan tanggung jawab semua orang percaya.

Pemulihan hubungan ini akan melahirkan kedamaian bagi manusia maupun alam, lebih dari itu kemuliaan Tuhan atas alam akan tampak jelas dan manusia sesungguhnya telah menjadi wakil Allah yang bertanggung jawab atas alam. Bertolak dari beberapa persoalan yang telah dipaparkan di atas, maka hal ini mendorong

\footnotetext{
${ }^{19}$ Haskarlianus Pasang, Mengasihi Lingkungan (Jakarta: Perkantas, 2010), 10.
} 
peneliti untuk mengkaji lebih jauh mengenai Ekologi Penciptaan dalam Kejadian 1-3 sebagai Landasan Evaluasi Kristis terhadap Perilaku Ekologis Para Teolog Reformed Indonesia Masa Kini.

Ekologi penciptaan adalah proses, cara dan perbuatan menciptakan yang mencakup seluruh lingkungan hidup secara menyeluruh baik tanah, hewan, tumbuhan serta organisme lainnya dalam alam termasuk manusia yang memiliki unsur keterkaitan dan ketergantungan antara satu dengan yang lain. Proses menciptakan itu sendiri dilakukan oleh Pribadi tertentu yang menciptakan, mengadakan, menjadikan dan atau membuatnya. Dalam konteks ini, Pencipta yang dimaksud adalah Allah Sang Pencipta.

Berdasarkan hal ini, pertanyaan penelitian sebagai berikut: pertama, Apakah yang dimaksud dengan makna ekologi penciptaan menurut kitab kejadian 1-3? Kedua, Bagaimanakah perilaku ekologis teolog reformed Indonesia masa kini? Ketiga, Bagaimanakah relevansi ekologi penciptaan menurut Kejadian 1-3 dalam mengatasi masalah kehidupan?

\section{METODOLOGI PENELITIAN}

Dalam meneliti artikel ini, penulis menggunakan pendekatan penelitian evaluasi dengan model Studi Kasus.

\section{ANALISIS DAN HASIL PENELITIAN}

Adapun temuan dalam penelitian ini menunjukkan bentuk perilaku ekologis teolog reformed adalah dengan menjalankan ekologi berdasarkan prinsip kelola bumi dan pelihara, dipanggill dalam satu garis menyatakan kebesaran Tuhan atas alam dimana alam menjadi jembatan untuk menyatakan Allah itu Pencipta. Sebagaimana yang nyata dalam teologia reformed adalah mandate budaya, bahwa manusia diciptakan untuk berbudaya dan budaya itu dipersembahkan untuk kemuliaan Allah.

Perilaku ekologis teolog reformed dinyatakan salah satunya dengan mengambil bagian dalam menjalankan tugas memelihara, mengelola ekologi dengan memberikan teladan, pola hidup yang benar pada pada lingkungan sekitar, hemat menggunakan air, listrik/energy, mengurangi penggunaan kertas, tissue, plastiK, terlibat dan melibatkan diri dalam kegiatan lingkungan. Salah satu bentuk tanggung jawab yang dapat dilakukan adalah dengan mulai menulis topik-topik mengenai ekologi baik dalam bentuk buku, jurnal, artikel serta dapat menyajikannya dalam bentuk seminar atau ceramah.

Menurut teolog reformed, ekologi berkenaan dengan alam semesta dalam kaitannya dengan panggilan manusia untuk memelihara dan mengelola alam dengan baik. Ekologi mengekspresikan keberadaan 
Allah dimana segala sesuatu diciptakan bagi kemuliaan Allah. jawaban ini sekaligus menyatakan bahwa teolog reformed selalu memperhatikan apa yang Alkitab ajarkan termasuk mengenai ekologi, sebagaimana Alkitab adalah landasan teolog reformed mengenai ekologi bahwa Allah menciptakan seluruh dunia dan memberikan mandate khusus kepada manusia untuk bertanggung jawab mengelola, memelihara alam dengan baik dan bukan merusaknya. Meski demikian di satu sisi teolog reformed masih kurang/sedikit sekali yang peduli secara praktis dan menjadi pelaku ekologis, bahkan ada keraguan jika keprihatinan terhadap ekologi itu belum terlalu kelihatan serta kecenderungan menyerahkan persoalan ekologi sebagai tanggung jawab pemerintah.

Harus diakui bahwa teolog reformed belum memiliki perilaku atau pengaruh yang kuat sebagai wujud perhatian terhadap ekologi, namun tentu ada pribadi-pribadi teolog reformed yang menunjukkan perhatian misalnya dengan mengurangi pemakaian kertas. Selain itu ekologi menjadi topik yang jarang bahkan hampir tidak pernah disampaikan melalui khotbah, karena pandangan bahwa tugas teolog reformed bukanlah sebagai praktisi yang memelihara alam, melainkan sebagai pendidik umat, selain itu tidak dipanggil sebagai penggiat ekologi namun tidak berarti teolog reformed ikut berbagian dalam mengekploitasi alam.

\section{KESIMPULAN}

Persoalan ekologi bukan hanya persoalan lingkungan sosial, ekonomi atau persoalan manusia saja, tetapi juga persoalan kemiskinan dan tentunya hal ini berakar pada krisis moral manusia itu sendiri, dengan kata lain manusia menjadi faktor utama terhadap kerusakan lingkungan dan manusia menderita akibat kejahatannya sendiri. Padahal dari sejak semula Allah telah mempercayakan kepemimpinan terhadap alam itu kepada manusia untuk mengelola dan memelihara ciptaan-Nya tersebut (Kej. 1-2). Namun pada kenyataannya tidak semua tugas itu berjalan dengan baik, hal ini terbukti dengan banyaknya pengrusakan alam (eksploitasi alam) yang dilakukan oleh manusia.

Berdasarkan Kejadian 1 dan 2, paling tidak ada tiga penegasan yakni: pertama, Allah memberikan manusia kekuasaan atas bumi dimana kekuasaan yang unik atas bumi adalah hubungan yang unik dengan Allah. Kedua, Kekuasaan manusia atas bumi adalah suatu kekuasaan kooperatif, artinya bahwa dalam menjalankan kekuasaan pemberian Allah, manusia bukannya menciptakan melainkan bekerja sama dengan prosesproses alami dan yang ketiga bahwa pendominasian manusia adalah pemberian karena itu suatu pendominasian yang bertanggung jawab dimana manusia menguasai bumi bukan berdasarkan hak 
melainkan berdasarkan perkenanan Allah. Dengan demikian jelas bahwa manusia bertanggung jawab kepada Allah dalam cara mengelola bumi ini.

\section{REKOMENDASI}

Beberapa implikasi yang diharapkan dapat menjadi masukan yang positif untuk peningkatan bagi pemahaman perilaku ekologis teolog reformed Indonesia masa kini, yaitu:

1. Meningkatkan perilaku ekologis yang nyata sehingga seimbang antara pemahaman teologis dan praktis.

2. Memikirkan ekologi sebagai suatu cakupan wilayah studi yang perlu diperhatikan dan dikembangkan misalnya mulai mengadakan penelitian berkenaan dengan topik ekologi, misalnya dengan menulis buku, jurnal, artikel, termasuk menyampaikan dalam khotbah.

3. Mengadakan kelas, seminar atau ceramah yang membahas isu-isu ekologis masa kini.

4. Melibatkan diri dalam kegiatan-kegiatan yang bersifat ekologis tanpa harus menjadi pejuang atau penggiat lingkungan/ekologis.

5. Memberikan contoh perilaku ekologis yang baik dan benar sehingga dapat menjadi teladan bagi orang yang dilayani maupun mahasiswa yang diajar.
6. Menerapkan sistem yang ramah ekologi, misalnya dengan hemat menggunakan plastik serta bangunan-bangunan yang banyak menggunakan kaca.air, memakai kertas atau tissue dengan tidak berlebihan, membatasi penggunaan.

\section{DAFTAR PUSTAKA}

Borrong, Robert P. Etika Bumi Baru. Jakarta: BPK Gunung Mulia, 2009.

Depdikbud. Keselamatan Lingkungan, untuk SGO. Jakarta: Mutiara, 1988.

Kodra, Hadi S. Ali. Global Warming, Banjir dan Tragedi Pembalakan Hutan. Bandung: Nuansa, 2008.

Stott, John Stott, Isu-isu Global Menantang Kepemimpinan Kristen. Jakarta: YKBK/OMF, 1994.

Pasang, Haskarlianus. Mengasihi Lingkungan. Jakarta: Perkantas, 2010.

Lumintang, Stevri Indra. Theology The Queen of Science \& The Master of Philosophy. Jakarta: Geneva Insani Indonesia, 2015.

Supardi, I. Lingkungan Hidup dan Kelestariannya. Bandung: Alumni, 1983.

Ichsan, Kesehatan Lingkungan. Jakarta: Depdikbud, 1979. 
Excelsis Deo: Jurnal Teologi, Misiologi, dan Pendidikan 